\title{
Calibrating Metronamica Land Use Simulation Model for Colombo, Sri Lanka
}

\author{
Chathura de Silva, Janithra Wimaladasa and Jagath Munasinghe \\ Department of Town \& Country Planning, University of Moratuwa, Sri Lanka \\ chthr.desilva@gmail.com,janithrac@yahoo.com,jagathnm@gmail.com
}

\begin{abstract}
Cellular Automata (CA) urban simulation models are widely used to explore the complexities associated with urban systems due to their simplicity, flexibility and intuitiveness, and particularly because of its ability to incorporate the spatial and temporal dimensions of the processes. This study is placed in a context where the current planning practices in Sri Lanka are in need of such robust methods and versatile techniques to comprehend land uses in rapidly growing urban areas. Metronamica is a broadly used cellular automata based modeling application that is capable of explore such land use dynamics. This paper present the findings of calibrating Metronamica urban simulation model for Colombo Metropolitan area in Sri Lanka. 1987 is taken as the base year of the calibration and 1987-2007 is considered as the calibration period. Eleven cell states are defined in the study while $100 \mathrm{~m} \times 100 \mathrm{~m}$ is taken as the cell size of the model. Calibration results are analyzed through the visual comparison, contingency table and kappa statistics.
\end{abstract}

Keywords: cellular automata (CA), land use changes, calibration, Metronamica

\section{Introduction}

Urban systems are becoming ever larger and increasingly complex as urban economies, social and political structures and norms, and transportation and other infrastructure systems and technologies evolve (Waddell \& Ulfarsson, 2004). Batty (2005) argued that our traditional image of the city no longer holds and cities appear much more complex than we generally assume. The situations generated with the growth of urban areas raise vital issues that need to be considered in the planning process (Pinto \& Antunes, 2010). One of the important subjects for concern in the field of urban planning $b$ is to explore the dynamic trends of land use transition. However, such attempts to understand the urban systems should be able to incorporate the uncertainties associated with the land use dynamics. Such uncertainties may arise due to numerous unknown factors involved (Cheng, Masser, \& Ottens, 2014).

Over the years urban simulation models have been developed using many approaches, to explore the mentioned complexities associated with land uses. Models are simplifications of reality - theoretical abstractions that represent systems in such a way that essential features crucial to the theory and its application are identified and highlighted. Initially developed urban land use models were based on the assumption that urban patterns are the changes in the equilibrium within the city system(Lahti, 2008), but there are limitations associated with this assumption - such as that of its centralized structure, lack of detail, little usability, flexibility and realism(Torrens \& O'Sullivan, 2001). Those models could not effectively capture the complex dynamics that shape city functions and hence, the land-uses there in. These traditional models were followed by 'complexity models' or 'geosimulation' models that were developed considering the bottom up approach in modeling process. Among a wide range of modeling techniques that are used for urban simulation, Cellular Automaton (CA) is considered as one that can effectively capture the complex nature of cities and its functions. CA is defined as 'an automaton of a processing mechanism with characteristics that change over time based on its internal characteristics, 
rules and external input' (Benenson \& Torrens, 2004).

The importance and the need of employing such tools in the planning process are widely recognized in Sri Lanka in a context where conventional urban planning practices lacked sound methods to predict the growth scenarios under different circumstances envisaged by development decisions.

This paper is a demonstrative attempt towards describing calibration results of the Metronamica urban Simulation model for Colombo, Sri Lanka by taking 1987 to 2010 as the calibration period. The first section of the paper briefly discusses the concepts associated with the $\mathrm{CA}$, its applications and the principles at the basic parameters of Metronamica model. The second section elaborates the methodology with study are, data preparation, model calibration process and applications. The third section discusses about the calibration results and the possibilities of further developing the model to explore the land use changes in Sri Lanka.

\section{Urban Simulation Modeling, Cellular Automata and Metronamica}

'Cellular automata' (CA) gets its name for it consists of cells - like the cells on a checkerboard - and that the cell states may evolve according to a simple transition rule, the automaton (RISK, n.d.). CA was first introduced in the 1940s by John von Neumann, the founder of game theory, and Stanislaw Ulam, did intensive research in the field of Monte Carlo simulation (Pinto \& Antunes, 2007). A conventional cellular automaton consists of (A) A Euclidean space divided into an array of identical cells-for geographical applications, a two or three dimensional array is most practical, (B) A cell neighborhood, for flow and diffusion processes the 4 (Von Neumann neighborhood) or 8 (Moore neighborhood) adjacent cells are sufficient, but for most socio-economic processes larger neighborhoods are required, (C) A set of discrete cell states, (D) A set of transition rules, which determine the state of a cell as a function of the states of cells in the neighborhood and (E) Discrete time steps, with all cell states updated simultaneously
(RISK, n.d.). A cell's new state is a function of all the states in the cell's neighborhood at the previous moment of time (or during the previous generation). We calculate a new state value by looking at all the previous neighborhood states. The fundamental formula for calculating a cell's state at any given time $t$ is:

CELL state at time $\mathrm{t}=\mathrm{f}(\mathrm{CELL}$ neighborhood at time $\mathrm{t}-1$ )

The CA model manages to capture the complexity in urban systems by capturing their characteristics of emergence, selfsimilarity, self-organization and non-linear behavior of land use changes with time (Micheal Batty \& Longley, 1994). The use of tools that can help in the understanding of the abovementioned characteristics is important to gain knowledge about the patterns and mechanisms behind urban dynamics (Sanchez, Z.Vojinovic, Price, \& Waly, 2011). Further these models can incorporate the local interactions in urban environments (Blecic, Cecchini, Prastacos, \& Trunfio, 2004). What makes CA-based models particularly attractive is their ability to "spontaneously" give rise to global dynamics out of local interaction rules (Michael Batty, 2005). Furthermore, these tools do not tend to simplify reality, but rather they employ complexity which makes them an effective instrument for the exploration of spatial dynamics (Blecic et al., 2004).

In terms of the use of CA in urban studies, several CA based applications are proposed and applied to various geographic - spatial phenomena and to understand the growth of different urban regions (Pinto \& Antunes, 2007). In recent years several scholarly attempts have been made on different theoretically under pinning issues regarding CA application to urban studies. Batty and Xie (1997) and Clarke, Hoppen, and Gaydos (1997) studied the application of important evolutions of CA to real world problems, Semboloni (2000) studied urban infrastructure development, O'Sullivan (2001)used an integrated approach based on CA and on graph theory to study gentrification, and, Silva and Clarke (2002) calibrated a CA modelSLEUTH (slope, land-use, exclusion, urban extent, transportation and hill shade)- to 
simulate the urban growth model for Lisbon and Porto, Portugal, while Barredo, Kasanko, McCormick, and Lavalle (2003) made applications of previously developed CA models to larger metropolitan areas.

As stated above, several cellular automata models have been developed during the past years to simulate the land use changes and to understand their complex nature. 'Metronamica' is one of the modeling applications that effectively captured this complex nature. Factors affecting land use changes in a particular context are dependent on the characteristics of the particular area. Therefore there is no set method to simulate land use changes in cities. Metronamica consists of a dynamic and spatial land use change model, and this can optionally include a regional migration model and a transport model for modeling congestion and traffic pressure on the transport network (RISK, n.d.).

Metronamica simulates land use changes based on a number of different drivers. First, there are external factors such as population growth or the decrease of natural land uses, such as deforestation or reclamation of marshy lands that determine the demand for different land uses. Population and jobs are divided over the regions, based on how attractive these regions are to people and businesses. This attractiveness depends again on a number of factors such as the existing activities and local characteristics such as the accessibility. Finally, within each region, the land uses for every location are determined based on socioeconomic factors (e.g., will a business flourish in this location?), policy options (e.g., are there policy rules in effect that restrict new housing development in this location?) and biophysical factors (e.g., is the soil suitable for agriculture here?) (RISK, n.d.).

\section{The Methodology of the study}

The Colombo Metropolitan Region (coincide with the Western Province, in terms of administrative boundaries), Sri Lanka was selected as the case study area for this study. The Colombo Metropolitan Region consists of three districts namely Colombo, Gampaha and Kalutara. The total land area of Colombo Metropolitan region is about 3,745 Square
Kilometers. Colombo, the capital city of Sri Lanka is situated within this region. It's the main administrative as well as the commercial hub in Sri Lanka.

As per the Department of Census and Statistics (2012), the total population of the region is $5,835,852$. As stated by the Central Bank (2012), Western province dominates as the main economic and administrative hub in the country and contributes almost 50\% for GDP of the country. The inbuilt framework of the Metronamica application is used as the framework for this study in the Colombo Metropolitan region (Western Province) to incorporate the effect of accessibility, interactions between land uses and the physical feasibility of different land-uses.

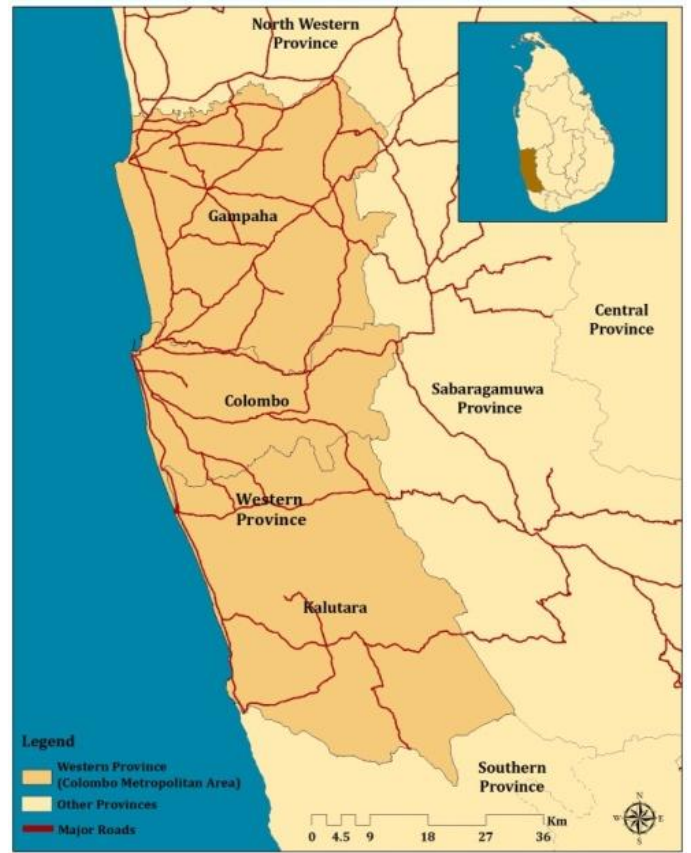

Figure 01: Colombo Metropolitan Region (Western Province)

\section{Cell structure}

Cell structure is considered as the first component of a CA model. The inbuilt regular cell structure of the Metronamica model is taken for this study. The cell size for the model was considered as $100 \mathrm{~m} \times 100 \mathrm{~m}$ (2.47acres).

\section{Cell states}

Eleven cell states were assigned for the model by taking eleven land use classes. Namely: 
"highly urbanized", "moderately urbanized", "less urbanized", "very less urbanized", "water bodies", "paddy", "marsh", "forest", "other crops/ cultivation", "sand/beach" and "rocks". In this, "highly urbanized", "moderately urbanized", "less urbanized", "very less urbanized", "paddy" and "marsh" are considered as functional cell states, while "forests", "rocks", "sand/ beach" and "water bodies" are considered as feature states- fixed cell states - which is assumed as not changing its states over time and "other crops" is considered as a vacant land use. Accordingly, the functional cell states can change its states with the model simulation. This means that land use dynamics are allowed in six land use classes. Meanwhile, the potential probability for changing the cell states and the strict legal framework exists in the country for preserving forests; beach and water resources are taken into consideration when assigning fixed cell states.

As the main consideration is on simulating urban growth pattern, the data set were prepared accordingly. In the original map layer, there was no land use category named "urban". Instead, there were categories named "built-up" and "homestead". So these two land uses were categorized into four urban categories namely highly, moderately, less and very less urban, based on the population density of the region. This is done through intersecting the land uses with population data using the Arc GIS application.

\section{Neighborhood}

The level to which land use interactions occur is incorporated to the CA model through the neighborhood component. For each location, each cell in the model assesses the quality and the character of its defined neighborhood. As Pinto and Antunes (2010) argued, neighborhood component plays a key role on the overall CA modeling framework since it represents the magnitude of interactions between different cells. This is embodying Tobler's theory on geography; "everything is related to everything else, but near things are more related than distant things"(Tobler, 1970). The neighborhood for the standard Metronamica model is defined to be a circular area with a radius of 8 cells containing 196 nearest cells (Delden, Escudero, Uljee, \& Engelen, 2005). The same is adopted in this study. In spatial terms, a neighborhood in CA represents a distance of $800 \mathrm{mfrom}$ a cell concerned.

\section{Transition rules / Neighborhood rules}

The dynamism of the CA models relies on the transition rules of a CA model. Cellular Automata models consider various factors in transition of land uses. Pre-defined rules of the original model are used in this study. In the Metronamica cellular automata land use model, there are pre-defined rules. It considers four factors; neighborhood effect, suitability, accessibility and zoning. Transition potential of a cell is determined by the result of all these four factors. Accordingly, the transition potential for land use function $\mathrm{f}$ in cell $\mathrm{c}$ $(\mathrm{tPf}, \mathrm{c})$ is calculated using the following equations:

$$
\begin{aligned}
& { }^{t} V_{f, c}= \begin{cases}{ }^{t} R_{f, c} \cdot(1+e) & \text { if } \alpha>0 \\
{ }^{t} R_{f, c} \text { else } & \end{cases}
\end{aligned}
$$

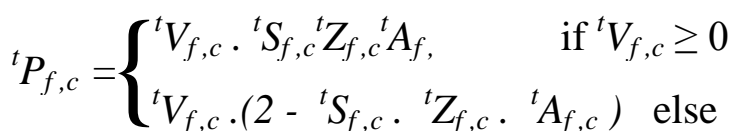

Here, transition potential is a multiplication of neighborhood potential (tRf ,c), suitability ( $\mathrm{S} \mathrm{f}$ ,c), zoning (tZf, c) and accessibility (tAf ,c). If a stochastic perturbation is included, two extra factors are taken into account: a random value drawn from a Weibull $(1 / \alpha, 1)$ distribution (e) and a parameter that controls the extent of the random effect in the potential $(\alpha)$. The value of this last parameter must be in the range $[0,1]$. For vacant states, the transition potential is: tPf, $c=t S f, c(R I S K$, n.d.). These four factors have been calculated separately. The findings of this paper are based on the simulations carried out with the neighborhood effect, suitability, and accessibility factors.

\section{Neighborhood Effect}

Neighborhood effect is dependent on the interaction of different land uses with each other. In the model, the neighborhood distance 
was set as 8 cells. So the influence functions are transformed to splines defined by only four points rather than calibrated to all 30 points. The points which give the influence functions are $(0$, inertia), $(1, a),(d, 0)$ and a point between the second and last point (RISK, n.d.).

$$
{ }^{t} R_{f, c}=\sum_{\substack{w \\ c^{\prime} \in D(c)}}\left(d\left(c, f\left(c^{\prime}\right), c^{\prime}\right)\right)
$$

${ }^{t} \mathrm{Rf}, \mathrm{c}=$ The neighborhood effect in cell $\mathrm{c}$ for land use $\mathrm{f}$ at time $\mathrm{t}$.

${ }^{t} \mathrm{f}(\mathrm{c})=$ The land use occupied by cell $\mathrm{c}$ at time t.

$\mathrm{d}(\mathrm{a}, \mathrm{b})=$ The Euclidian distance between cell $\mathrm{a}$ and cell $b$

$\mathrm{W}_{\mathrm{f}, \mathrm{f}}(\mathrm{d})=$ The influence function, expressing the strength of the influence of a cell with land use $f^{\prime}$ on land use $f$ for each distance $d$ in the CA neighborhood.

\section{Suitability}

Physical suitability maps are based on physical characteristics of a location. These remain constant during simulation, but affect the transition rules.

\section{Accessibility}

Accessibility measures the effect of the nearness and importance of different types of transport networks - such as local roads, highways or railroads - on the possible future occurrence of each land use function on a certain location (RISK, n.d). Further the accessibility is used to calculate the Transition potential values of each cell. In the complete ${ }^{1}$ Metronamica model, the accessibility for each land use function is a composite measure of four types ${ }^{2}$ of accessibility: zonal accessibility, local accessibility, implicit accessibility and

\footnotetext{
1 - Metronamica complete model is comprised of land use, regional and transport models. In this study on the land use model is used for the calibration.

${ }^{2}$ - The zonal accessibility is a measure based upon the generalized cost from a transport zone to origins and destinations. This is calculated in the transport model of the Metronamica. The local accessibility reflects the extent to which the need for the presence or absence of the transportation network of a land use can be fulfilled. The implicit accessibility reflects the fact that when an area is occupied by an urban land use, measures will be taken to assure its accessibility.
}

explicit accessibility (RISK, n.d.). These four types of accessibility are combined in a single value in the range $(0,1)$ for each land use and each cell, expressing the effect that the transportation network has on the possible future occurrence of that land use in that cell.

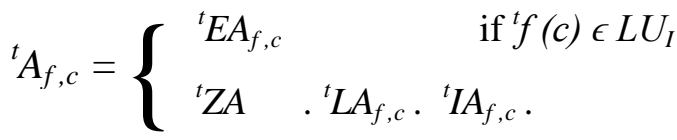

${ }^{t} \mathrm{EA}_{\mathrm{f}, \mathrm{c}}=$ the explicit accessibility of cell $c$ for land use $f$

${ }^{\mathrm{t}} \mathrm{f}(\mathrm{c})=$ the land use occupied by cell $c$

$\mathrm{LU}_{\mathrm{I}}=$ The set of impassable land uses

${ }^{\mathrm{t}} \mathrm{ZA}_{\mathrm{f}, \mathrm{z}}=$ the zonal accessibility for land use function $f$ in transport zone $z, z_{c}$ the transport zone, in which cell $c$ is located

${ }^{\mathrm{t}} \mathrm{LA}_{\mathrm{f}, \mathrm{c}}=$ Local accessibility of cell $c$ for land use $f$

${ }^{t} \mathrm{IA}_{\mathrm{f}, \mathrm{c}}=$ The implicit accessibility of cell $c$ for land use $f$ (RISK, n.d.)

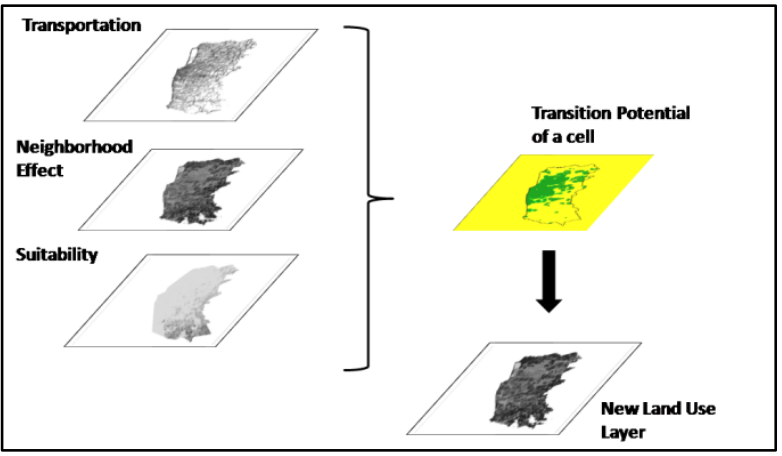

Figure 02: Conceptual Illustration on the Modeling Framework

\section{Calibration framework}

CA models need to be calibrated in order to ensure the best possible application between the simulated outcomes and the reality that is being modeled. The time step of this model is taken as one year. During each time loop, the model is dynamically evolved. Figure 03 represents the overall modeling process. The calibration results were validated with the contingency table, Kappa statistics and visual comparison method. This had offered three different methods ${ }^{3}$ to qualify and quantify the results.

\footnotetext{
3 - Contingency table method is considered as a tool to compare the global performance of the model. This table is developed and calculated by analyzing the total number of cells in a certain category (cell state) that have changed in simulation and reality. Kappa statistics consider the overall satisfactory level of the
} 


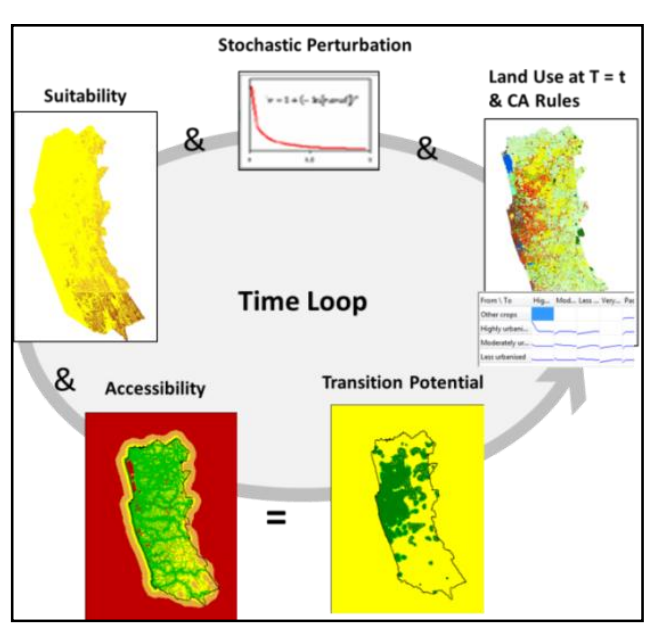

Figure 03: Modeling Process

\section{Neighborhood influence parameter}

Neighborhood effect is defined based on the attraction and repulsion between different land uses. Among the land use categories, a set of land use pairs that has high levels of interaction were selected and then the rules were defined. The model is run until the end of the calibration period, and the final land use map generated by the model is compared with the actual land use map of 2010. When the maps did not approximate enough, the rules were changed, and the model was run again. This process was continued until having a high degree of similarity between the model output and the real map. The values of the influence were based on the knowledge gained through literature review. Relative influence values for each cell state type is assigned to calculate the transition potential of each cell.

\section{Accessibility parameters}

Accessibility parameters were set considering the influence on functional land uses by Major roads, minor roads, Jeep/ cart tracks, footpaths and railway line and stations. Accessibility for urbanized land uses were considered more important than the other land uses. So, the accessibility parameters were defined accordingly. Marsh, water bodies, sand/ beaches and rock/ quarry land uses were considered impassable land uses for networks.

model and satisfactory level of each cell state. Visual comparison method provides a series of maps that enable the researcher to visually compare the simulated results with the actual results RISK, n.d.)

\section{Preparation of dataset}

Data and data sources

Dataset required for the model were basically collected from the Survey Department and the Department of Census and Statistics. Land use maps were prepared using the data shape files obtained from the Survey Department of Sri Lanka. Data was only available for two years. The Slope map was prepared using the DEM (Digital Elevation Map) layer in Arc GIS application. Road networks and railway stations were considered for the accessibility. Road layers were considered for two years. Initial layer in 1987 and the road network changes of main roads in 1996.

\begin{tabular}{|l|c|c|c|l|}
\hline \multirow{2}{*}{$\begin{array}{c}\text { Road } \\
\text { Category }\end{array}$} & \multicolumn{2}{|c|}{ Highly Urbanized } & \multicolumn{2}{c|}{$\begin{array}{c}\text { Moderately } \\
\text { Urbanized }\end{array}$} \\
\cline { 2 - 5 } & $\begin{array}{c}\text { Distance } \\
\text { Decay }\end{array}$ & Weight & $\begin{array}{c}\text { Distanc } \\
\text { e Decay }\end{array}$ & Weight \\
\hline $\begin{array}{l}\text { Main } \\
\text { Roads }\end{array}$ & $1 \mathrm{~km}$ & 1 & $2 \mathrm{~km}$ & 0.7 \\
\hline $\begin{array}{l}\text { Minor } \\
\text { Roads }\end{array}$ & $500 \mathrm{~m}$ & 0.75 & $1 \mathrm{~km}$ & 0.7 \\
\hline $\begin{array}{l}\text { Jeep/ } \\
\text { Cart } \\
\text { Tracks }\end{array}$ & $250 \mathrm{~m}$ & 0.5 & $500 \mathrm{~m}$ & 0.6 \\
\hline Footpath & $50 \mathrm{~m}$ & 0.2 & $100 \mathrm{~m}$ & 0.3 \\
\hline $\begin{array}{l}\text { Railway } \\
\text { Stations }\end{array}$ & $500 \mathrm{~m}$ & 0.1 & $500 \mathrm{~m}$ & 0.1 \\
\hline
\end{tabular}

Table 01: Accessibility Parameters for the Model

\section{Preparation of dataset}

Data and data sources

Dataset required for the model were basically collected from the Survey Department and the Department of Census and Statistics. Land use maps were prepared using the data shape files obtained from the Survey Department of Sri Lanka. Data was only available for two years. The Slope map was prepared using the DEM (Digital Elevation Map) layer in Arc GIS application. Road networks and railway stations were considered for the accessibility. Road layers were considered for two years. Initial layer in 1987 and the road network changes of main roads in 1996. 


\begin{tabular}{|l|c|l|}
\hline \multicolumn{1}{|c|}{ Data } & $\begin{array}{c}\text { Type of } \\
\text { Data }\end{array}$ & \multicolumn{1}{c|}{ Source } \\
\hline $\begin{array}{c}\text { Land use maps } \\
(1987 \& 2010)\end{array}$ & $\begin{array}{c}\text { Shape } \\
\text { files }\end{array}$ & Survey Department of Sri Lanka \\
\hline Population data & $\begin{array}{c}\text { Shape } \\
\text { files }\end{array}$ & Department of Census and Statistics \\
\hline $\begin{array}{l}\text { Road and Railway } \\
\text { Network }\end{array}$ & $\begin{array}{c}\text { Shape } \\
\text { files }\end{array}$ & $\begin{array}{l}\text { Survey Department of Sri Lanka } \\
\text { Road Development Authority of Sri Lanka }\end{array}$ \\
\hline Elevation data & $\begin{array}{c}\text { Shape } \\
\text { files }\end{array}$ & Survey Department of Sri Lanka \\
\hline
\end{tabular}

Table 02: Data and Data Sources

\section{Macro Model Data}

Overall demand for functional land uses in 1987 and 2010 were defined in the model at the beginning as to indicate whether those land uses increase or decrease. Cell counts for each land use for both 1987 and 2010 were obtained from respective land use maps. The growth was considered as a linear growth and cell count for all the functional land use categories were increased during the above period.

\section{Results and Discussion}

The model was calibrated by taking 1987 as the base year and for the period of 1987-2010. The model was calibrated by 20 occasions to achieve the satisfied level.

\section{Contingency table}

Contingency table details the cross distribution of categories on the two maps selected. The table 4 is expressed in number of cells.

\begin{tabular}{|l|c|c|c|}
\hline \multicolumn{1}{|c|}{ Land Use Category } & Cell Count (1987) & Cell Count (2010) & $\mathbf{1 9 8 0 - 2 0 1 0 ( + / - ) ~ \% ~}$ \\
\hline Highly urbanized & 14675 & 15000 & 2.21 \\
\hline Moderately urbanized & 11093 & 16497 & 48.72 \\
\hline Less urbanized & 25962 & 31705 & 22.12 \\
\hline Very less urbanized & 48825 & 50471 & 3.37 \\
\hline Paddy & 61495 & 63644 & 3.49 \\
\hline Marsh & 3456 & 3543 & 2.52 \\
\hline
\end{tabular}

Table 03: Macro Model Dataset Preparation

\begin{tabular}{|l|r|r|r|r|r|r|r|c|}
\hline & \multicolumn{1}{|c|}{$\begin{array}{l}\text { Other } \\
\text { Crops }\end{array}$} & $\begin{array}{l}\text { Highly } \\
\text { Urbanized }\end{array}$ & $\begin{array}{l}\text { Moderately } \\
\text { Urbanized }\end{array}$ & $\begin{array}{l}\text { Less } \\
\text { Urbanized }\end{array}$ & $\begin{array}{l}\text { Very Less } \\
\text { Urbanized }\end{array}$ & Paddy & Marsh & $\begin{array}{c}\text { Total in } \\
\mathbf{1 9 8 7}\end{array}$ \\
\hline $\begin{array}{l}\text { Other } \\
\text { Crops }\end{array}$ & 110,888 & 1739 & 1834 & 4651 & 11,017 & 22,989 & 126 & $\mathbf{1 5 3 , 2 4 4}$ \\
\hline $\begin{array}{l}\text { Highly } \\
\text { Urbanized }\end{array}$ & 2414 & 8871 & 2018 & 509 & 148 & 640 & 75 & $\mathbf{1 4 , 6 7 5}$ \\
\hline $\begin{array}{l}\text { Moderately } \\
\text { Urbanized }\end{array}$ & 2253 & 615 & 5777 & 1392 & 322 & 734 & 0 & $\mathbf{1 1 , 0 9 3}$ \\
\hline $\begin{array}{l}\text { Less } \\
\text { Urbanized }\end{array}$ & 6005 & 776 & 2270 & 12,631 & 1871 & 2400 & 9 & $\mathbf{2 5 , 9 6 2}$ \\
\hline $\begin{array}{l}\text { Very Less } \\
\text { Urbanized }\end{array}$ & 13,300 & 537 & 707 & 4741 & 26,753 & 2787 & 0 & $\mathbf{4 8 , 8 2 5}$ \\
\hline $\begin{array}{l}\text { Paddy } \\
\text { Marsh }\end{array}$ & 2832 & 2358 & 3840 & 7769 & 10,315 & 34,086 & 295 & $\mathbf{6 1 , 4 9 5}$ \\
\hline $\begin{array}{c}\text { Total in } \\
\mathbf{2 0 0 0}\end{array}$ & $\mathbf{1 3 7 , 8 9 0}$ & $\mathbf{1 5 , 0 0 0}$ & $\mathbf{1 6 , 4 9 7}$ & $\mathbf{3 1 , 7 0 5}$ & $\mathbf{5 0 , 4 7 1}$ & $\mathbf{6 3 , 6 4 4}$ & $\mathbf{3 5 4 3}$ & \\
\hline
\end{tabular}

Table 04: Contingency Table for Land use Map of 1987 (Horizontal) and 2010 (Vertical) 
According to the results shown in table 03, it clearly shows that highly urbanized lands have been converted into other land uses although the rule was given to prevent that. But most of the highly urbanized lands have remained the same. Other land use categories also show this same pattern. As it is indicated in the table 03, marsh has been correctly simulated to a considerable degree converting in fewer amounts into any other land use (Out of 3456 cells in 1987, 3038 cells remained as marshes while the other cells had changed in to another cell state).

\section{Kappa Statistics}

Kappa is the measure of agreement between the two categorical maps. This measurement is used to assess the overall validity of the model. It is less than or equal to 1 . A value of 1 indicates perfect agreement and values less than 1 indicate less than perfect agreement. This can be interpreted as follows (table 05):

\begin{tabular}{|l|c|}
\hline \multicolumn{1}{|c|}{ Agreement } & Value range \\
\hline Poor agreement & Less than 0.20 \\
\hline Fair agreement & 0.20 to 0.40 \\
\hline Moderate agreement & 0.40 to 0.60 \\
\hline Good agreement & 0.60 to 0.80 \\
\hline Very good agreement & 0.80 to 1.00 \\
\hline
\end{tabular}

Table 05: Defining Kappa Measure -Agreement and Values

Kappa for this model map is 0.467 which is a moderate agreement. It should be more than 0.8 to be a 'very good agreement'. But these results indicate that the modeled map has a 'moderate agreement' to the original map (table 06 ).

\begin{tabular}{|l|c|}
\hline Land Use / cell states & Kappa values \\
\hline Highly Urbanized & 0.427 \\
\hline Moderately Urbanized & 0.255 \\
\hline Less Urbanized & 0.297 \\
\hline Very Less Urbanized & 0.393 \\
\hline Paddy & 0.403 \\
\hline Marsh & 0.815 \\
\hline
\end{tabular}

Table 06: Kappa Values for Simulated Maps

Kappa of individual land use categories indicates a 'very good agreement' of marsh which is 0.815 . Paddy and Highly urbanized land use are under a moderate agreement and moderate and less urbanized land uses are within fair agreement.

\section{Visual Interpretation}

Visual comparison is recognized as one of the suitable methods used in the calibration process. Changes which have been occurred during the years can be observed visually which gives a clear idea of how different land uses have been changed or distributed over the years. For the visual comparison, three maps were used; Initial land use map of 1987, 2010 Land use map, and Modeled 2010 land use map.

In considering the differences between the actual land use map of 2010 and the modeled map of 2010, it displays the number of overlapping cells in both maps.

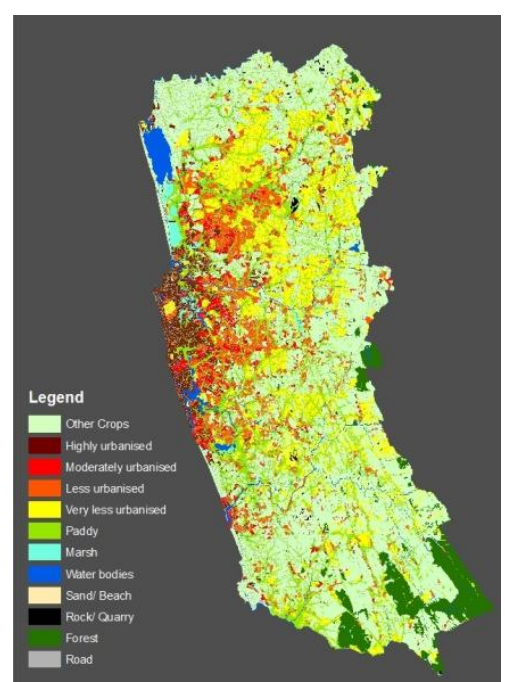

Initial Land Use Map 1987

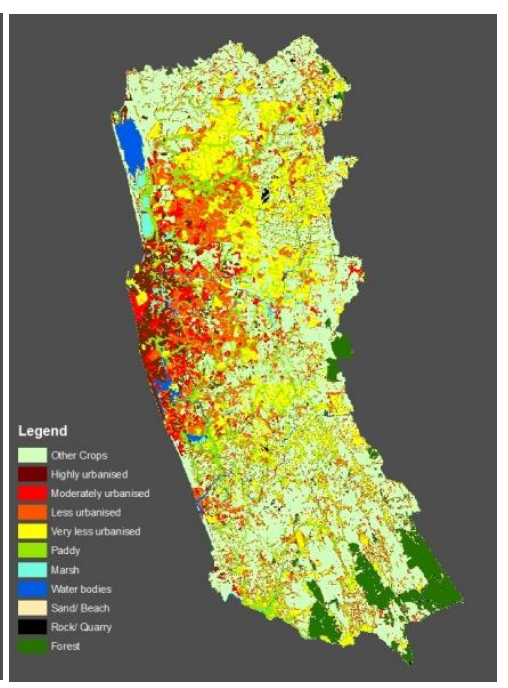

Actual Land Use Map 2010

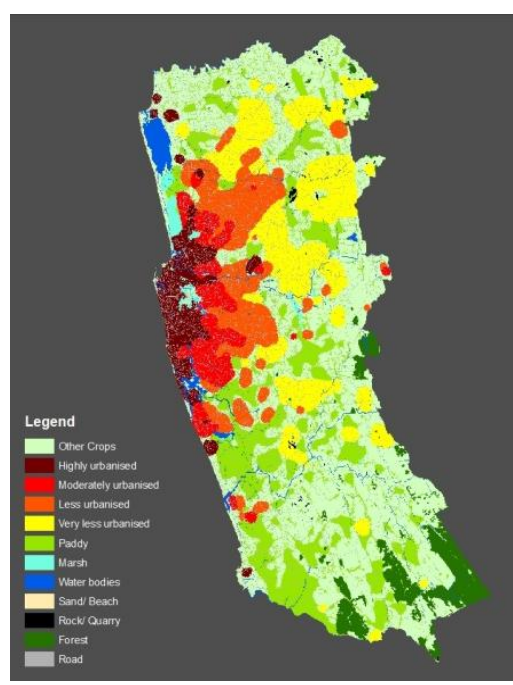

Modeled Land Use Map 2010

Figure 04: Visual Representation of Actual Maps (1987 and 2010) and Simulated Map 2010 


\begin{tabular}{|l|c|c|c|c|}
\hline \multicolumn{1}{|c|}{$\begin{array}{c}\text { Land Use } \\
\text { Category }\end{array}$} & $\begin{array}{c}\text { Cell count } \\
\text { in 2010 } \\
\text { Actual } \\
\text { Map }\end{array}$ & $\begin{array}{c}\text { No of cells in Both } \\
\text { 2010 modeled map } \\
\text { and 2010 Actual } \\
\text { map }\end{array}$ & $\begin{array}{c}\text { No of cells in } \\
\text { modeled 2010 } \\
\text { map which not } \\
\text { overlapping with } \\
\text { 2010 Actual map }\end{array}$ & $\begin{array}{c}\text { Level of } \\
\text { Accuracy } \\
\text { (Percentage) }\end{array}$ \\
\hline Highly Urbanized & 15000 & 6745 & 8255 & 44.97 \\
\hline $\begin{array}{l}\text { Moderately } \\
\text { Urbanized }\end{array}$ & 16497 & 4752 & 11745 & 28.81 \\
\hline Less Urbanized & 31705 & 11313 & 20392 & 35.68 \\
\hline Very Less Urbanized & 50471 & 23980 & 26491 & 47.51 \\
\hline Paddy & 63644 & 32081 & 31563 & 50.41 \\
\hline Marsh & 3543 & 2892 & 651 & 81.63 \\
\hline
\end{tabular}

Table 07: Analysis of the Simulation Results with Global Measure

\begin{tabular}{|l|c|c|c|}
\hline \multicolumn{1}{|c|}{ Land Use Category } & In both Maps & Only in map 1 (1987) & $\begin{array}{c}\text { Only in Map 2 (actual } \\
\text { 2010) }\end{array}$ \\
\hline Highly Urbanized & 10254 & 4421 & 4746 \\
\hline Moderately Urbanized & 6471 & 4622 & 10026 \\
\hline Less Urbanized & 18356 & 7606 & 13349 \\
\hline Very Less Urbanized & 40216 & 8609 & 10255 \\
\hline Paddy & 56412 & 5083 & 7232 \\
\hline Marsh & 3239 & 217 & 304 \\
\hline
\end{tabular}

Table 08: Map Comparison (1987 with Actual 2010 Map)

\begin{tabular}{|l|c|c|c|}
\hline \multicolumn{1}{|c|}{ Land Use Category } & $\begin{array}{c}\text { In } \\
\text { both } \\
\text { Maps }\end{array}$ & Only in map 1 (1987) & $\begin{array}{c}\text { Only in Map 2 (Modeled } \\
\text { 2010) }\end{array}$ \\
\hline Highly Urbanized & 8871 & 5804 & 6129 \\
\hline Moderately Urbanized & 5777 & 5316 & 10720 \\
\hline Less Urbanized & 12631 & 13331 & 19074 \\
\hline Very Less Urbanized & 26753 & 22072 & 23718 \\
\hline Paddy & 34086 & 27409 & 29558 \\
\hline Marsh & 3038 & 418 & 505 \\
\hline
\end{tabular}

Table 09: Map Comparison (1987 with modeled 2010 Map)

According to the comparison, it clearly shows that the model has been capable to generate the patterns of marsh land to a higher extent which is 81.63 percent. Among urban categories, very less urbanized $(47.51 \%)$ land use is the most correctly simulated land use and secondly the highly urbanized land (44.97\%). Paddy also has been simulated with more than 50 percent of accuracy. But the model has not been capable of generating patterns in urbanized land uses with a higher level of accuracy.

The comparison between the 1987 land use maps with the actual land use map of
2010 and the modeled map of 2010 shows how the land uses appeared and disappeared within the region and how land uses have been changed. It also shows to what level the modeled map has been capable to simulate the change between two years. 


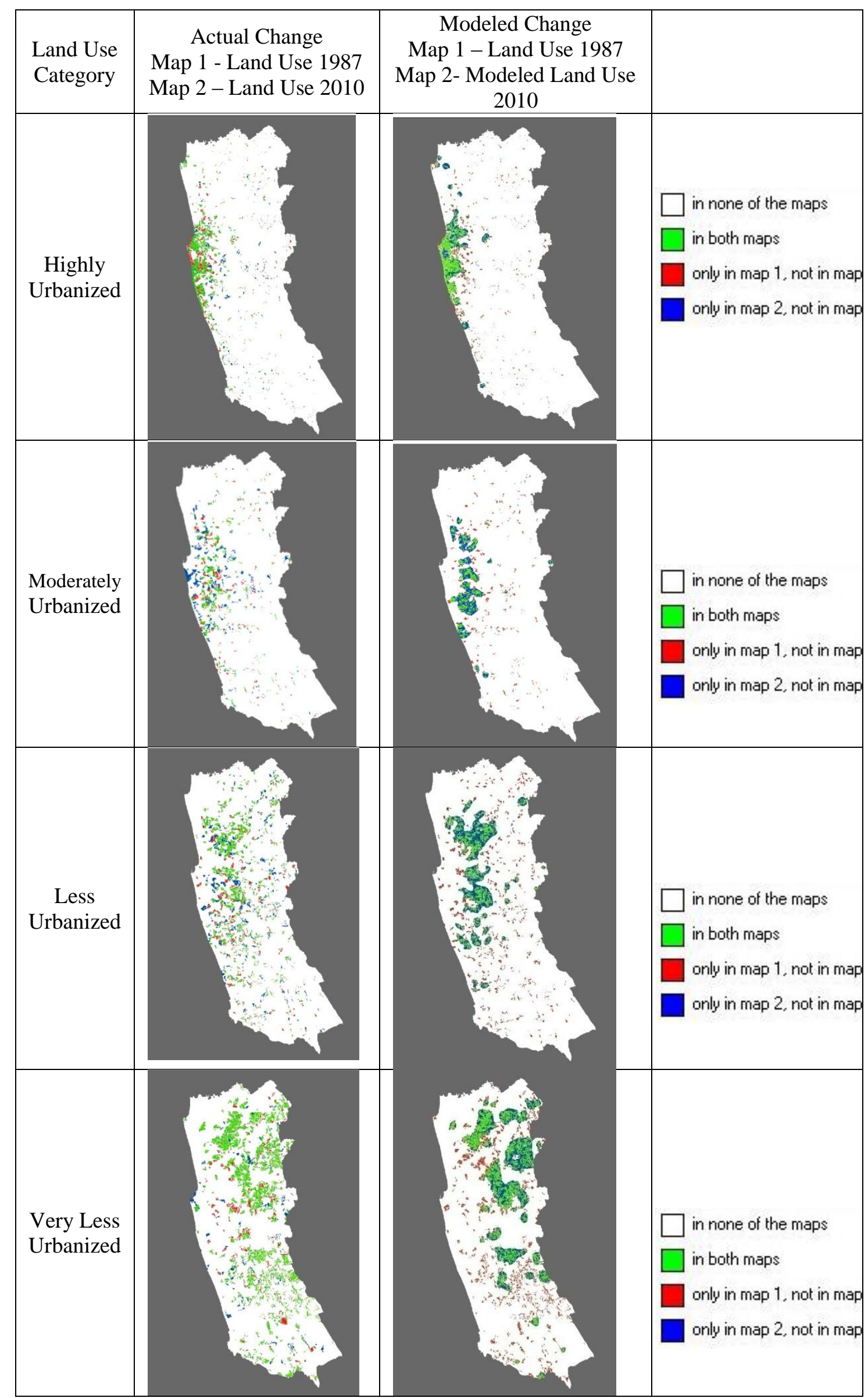




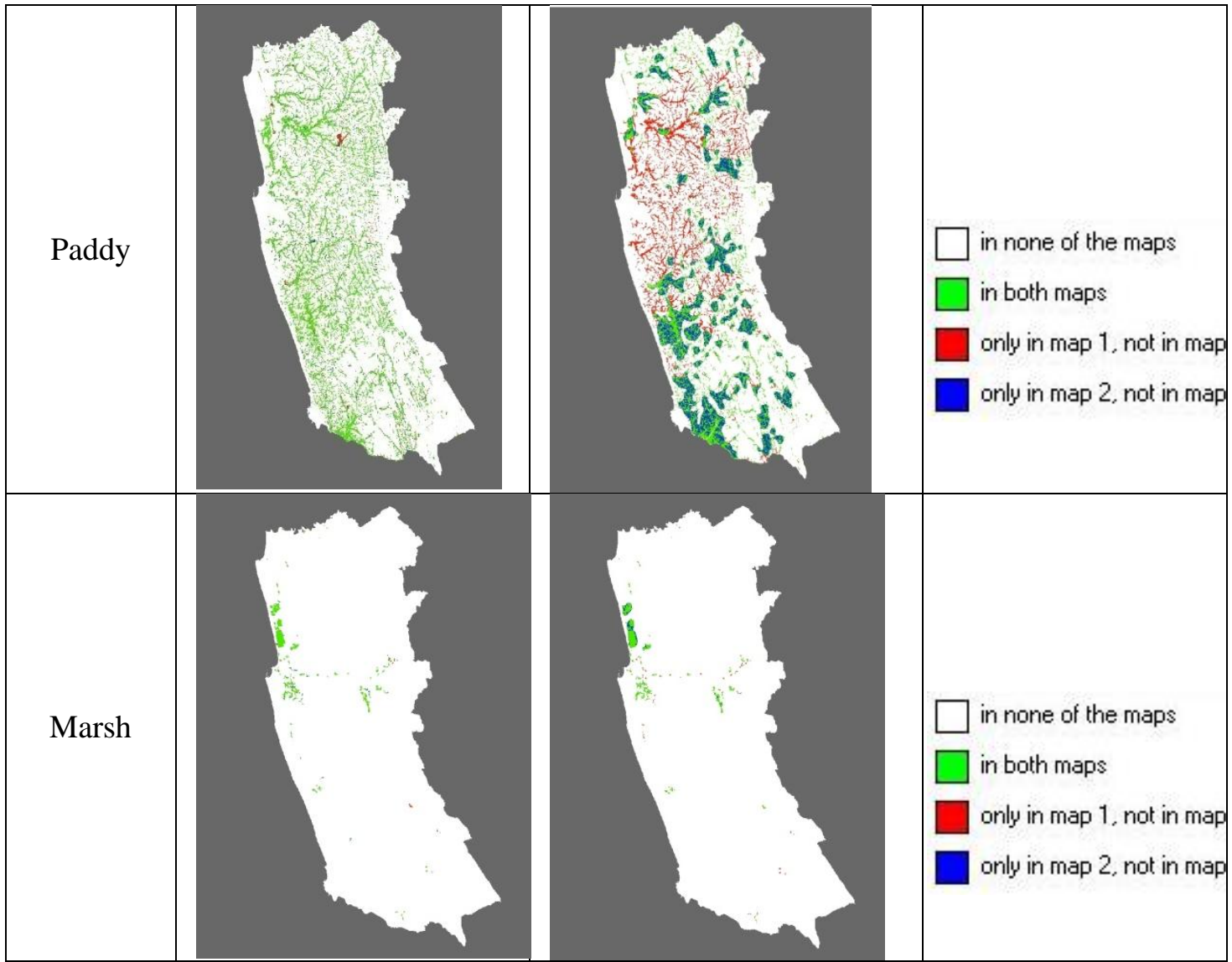

Figure 05: Comparing the Actual Change and Model Change from 1987- 2010 for Selected Land use Categories

These calibration results show that the model has been capable of modeling marsh lands with a great level of accuracy. In the modeled map, land uses have been concentrated in many places and the small patches have disappeared.

According to the analysis, the model has been $81.63 \%$ successful in capturing the changes in marshy category. Urban land use category (highly urbanized, moderately urbanized, less urbanized and very less urbanized) is simulated with a success rates between 40 $50 \%$. It is understood that the model need to be calibrated by changing the assigned neighborhood rules.

\section{Conclusions}

The findings of the study indicates the possibilities of employing this model as a potential tool in simulating urban land uses in Sri Lanka. It is found that the model simulates the changing pattern of marshy lands with a high level of accuracy. Simulations of highly urbanized and less urbanized land uses also showed relatively higher levels of accuracy level of $40-50 \%$.

As Byrne (1997) stated, the simulation is clearly a tool which helps us not to know what will happen, but what can be made to happen. More importantly, this modeling exercise opened up further avenues to explore more on land use dynamics and to investigate the validity of the results obtained from a simulation of this nature and the contingencies involved in it.

Despite the promising results of the application of the model, there is significant space for further improvements and customization of the model before applying as a tool in the decision making process. The fundamental idea of CA models is that the state of a cell at any time depends on the states of the cells within its neighborhood. Therefore results of a model are expected to change with the assigned neighborhood rules and the neighborhood effect. Further studies on this research can be focused to increase the number of calibrations by changing the neighborhood rules and neighborhood effect. 


\section{REFERENCES}

Barredo, J. I., Kasanko, M., McCormick, N., \& Lavalle, C. (2003). Modelling dynamic spatial processes: simulation of urban future scenarios through cellular automata. Landscape and Urban Planning, 64(3), 145-160.

Batty, M. (2005). Cities and Complexity: Understanding Cities with Cellular Automata, Agent-based Models, and Fractals: MIT Press.

Batty, M., \& Longley, P. (1994). Fractal cities - a geometry of form and function. London, UK: Academic Press.

Batty, M., \& Xie, Y. (1997). Possible urban automata. Environment and planning B: planning and design, 24(2), 175-192. doi: 10.1068/b240175

Benenson, I., \& Torrens, P. M. (2004). Geosimulation: Automata-based Modeling of Urban Phenomena: John Wiley, Chichester, Sussex.

Blecic, I., Cecchini, A., Prastacos, P., \& Trunfio, G. A. (2004). Modelling urban dynamics with cellular automata: A model of the city of Heraclion. Paper presented at the 7th AGILE conference on geographic information science.

Byrne, H. M. (1997). The importance of intercellular adhesion in the development of carcinomas. Mathematical, medicine and biology, 14(4), 305-323. doi: 10.1093/imammb/14.4.305

Cheng, J., Masser, I., \& Ottens, H. (2014). Understanding urban growth system: theories and methods. Retrieved from http://www.researchgate.net/publication/228588435_Understanding_urban_ growth_system_theories_and_methods website:

Clarke, K. C., Hoppen, S., \& Gaydos, L. (1997). A self-modifying cellular automaton model of historical urbanization in the San Francisco Bay area. Environment and planning B: planning and design, 24(2), 247-261. doi: 10.1068/b240247

Couclelis, H. (1997). From cellular automata to urban models: new principles for model development and implementation. Environment and planning B: planning and design, 24(2), 165-174. doi: $10.1068 / \mathrm{b} 240165$

Delden, H. v., Escudero, J. C., Uljee, I., \& Engelen, G. (2005). Metronamica: a dynamic spatial land use model applied to Vitoria- Gasteiz. Paper presented at the Virtual seminar of MILES project, Vitoria- Gasteiz.

Fertner, C., Jørgensen, G., \& Nielsen, T. A. S. (2012). Land use scenarios for greater Copenhagen : modelling the impact of the Fingerplan. Journal of Settlements and Spatial Planning, 3(1), 1-10.

Lahti, J. (2008). Modelling urban growth using cellular automata. (Masters Thesis), International Institute for Geo-Information Science and Earth Observation Enschede. Retrieved from http://www.itc.nl/library/papers_2008/ msc/gem/lahti.pdf

O'Sullivan, D. (2001). Graph-cellular automata: a generalised discrete urban and regional model. Environment and planning B: planning and design, 28, 687-705. doi: 10.1068/b2707

Pinto, N. N., \& Antunes, A. P. (2007). Cellular automata and urban studies: a literature survey. ACE: Arquitectura, Ciudad y Entorno, 3.

Pinto, N. N., \& Antunes, A. P. (2010). A cellular automata model based on irregular cells: application to small urban areas. Environment and planning B: planning and design, 37, 1095-1114. doi: $10,1068 / \mathrm{b} 36033$

RISK. (n.d.). Metronamica documentation: Research Institute for Knowledge Systems, Maastricht, The Netherlands. 
Sanchez, A., Z.Vojinovic, Price, R., \& Waly, M. (2011). Towards an Approach to the Evolution of Urban Drainage Networks Using Agent-Based Models. Paper presented at the 12nd International Conference on Urban Drainage, Porto Alegre/Brazil.

Semboloni, F. (2000). The growth of an urban cluster into a dynamic self-modifying spatial pattern. Environment and planning B: planning and design, 27(4), 549 - 564. doi: 10.1068/b2673

Silva, E. A., \& Clarke, K. C. (2002). Calibration of the SLEUTH urban growth model for Lisbon and Porto, Portugal. Computers, Environment and Urban Systems, 26(6), 525-552.

Tobler, W. (1970). A computer movie simulating urban growth in the Detroit region. Economic geograpohy, 4, 234-240.

Torrens, P. M., \& O'Sullivan, D. (2001). Editorial-cellular automata and urban simulation: where do we go from here? Environment and planning B: planning and design, 28, 163 - 168. doi: DOI:10.1068/b2802ed

Waddell, P., \& Ulfarsson, G. F. (2004). Introduction to urban simulation: design and development of operational. University of Washington.

White, R., \& Engelen, G. (1997). Cellular automata as the basis of integrated dynamic regional modelling. Environment and planning B: planning and design, 24(2), 235-246.

Wickramasuriya, R. C. (2007). Application and assessment of usability of the land use model Metronamicaa case study in the southern Sri Lanka. (Master of Science), Wageningen University The Netherlands. (GIRS-2007-01) 